\title{
ON THE IDEA OF TRUE PHILOSOPHY
}

\author{
Viktor I. Polishchuk*, Zoya Ya. Selitskaya, Grogory V. Silchenko, Evgenia A. Yurinova, \\ Irina G. Vyushkova
}

Tyumen State University, 10 Semakova Str., Tyumen, 625003, Russia

Published online: 15 February 2017

\begin{abstract}
Background: Discussions on the actual role and status of philosophy continuously arise, especially at the time of crises, abrupt changes to habitual ways of life and patterns of thought and behavior. Throughout the $20^{\text {th }}$ century philosophical thought, both in the West and in Russia, has undergone a number of major reconsiderations, with controversial outcomes. Philosophy was, in fact, transformed into ideology, i.e. a system of beliefs that ultimately serves the interests of the ruling elite and has a definite apologetic aim - to justify the existing social arrangements and foster the required unanimity of opinions in the society. Liberal arts students and anyone pursuing philosophical studies are taught that the true philosophy is philosophy of science, while philosophy per se does not deserve serious attention because such philosophy is a relic of the past.
\end{abstract}

Objective: The article aims to reveal the causes of the decline of philosophy, to reclaim the status and meaning of true philosophy, and to forecast its perspective development in the modern world. To meet these objectives the authors make use of the analytical, historical, cultural, comparative and hermeneutical methods of research.

Results: The article gives substantial evidence to the fact that the inability of modern philosophy to address urgent political, social, etc. issues in Russia is the result of its deliberate three-stage transformation into ideology throughout the $20^{\text {th }}$ century.

It is demonstrated that the philosophy of culture is the modern way of philosophizing and the true philosophy of our time.

doi: http://dx.doi.org/10.4314/jfas.v9i1s.728 
The article highlights some unresolved issues connected with this approach: the essence of culture; the principles, laws and the purpose of cultural development; the correlation between culture and life.

The article also argues that the ultimate goal of unraveling the meaning of modern philosophy is to go from the philosophy "about something" to the philosophy of the person generated by his/her independent thought. This kind of further development is only possible in the situation of academic freedom and the person's independence in finding and absorbing knowledge.

Conclusion: The contribution of this study to the contemporary philosophical discourse is threefold: firstly, it demonstrates that the role and status of modern philosophy are different from and surpass those of narrower fields of knowledge; secondly, it defines modern philosophy as the philosophy of culture; thirdly, it envisions the future of modern philosophy as the philosophy generated by the person capable of independent thinking.

This study can be applied to interpreting and evaluating current and past social issues from a cultural and philosophical standpoint.

Key words: philosophy, true philosophy, modern philosophy, culture, philosophy of culture.

\section{INTRODUCTION}

The issue of the status of philosophy is certainly not new - it is as old as philosophy itself. And yet, every philosopher comes to a point in his work when he faces the question, "What is true philosophy and what is its role in the modern world?" Attempts have been made to find a conclusive answer to this question, with interesting results. For example, the contemporary Russian philosopher V.A. Lektorsky in his book "Philosophy, cognition, culture" proposes that philosophy, as a way of understanding the world and man, examining culture and its foundations, at the same time establishes a link between the three worlds in which the person lives - the ordinary real-life world, the world of subjective experiences and the specialized world of science. By identifying and clarifying the relationship between these three worlds, philosophy simultaneously formulates (should formulate!) some ideal, some program of action of man and society as a whole: "... philosophy is an important regulatory component that defines the future state and designs cultural and human reality" (Lektorsky, 2012). This idea is very important for today's Russia and its intellectual elite, whose members still cannot clearly say what sort of society we want to build (Nikiforov, 2013).

Another prominent Russian philosopher, V.M. Mezhuev, highlighted the issue of the crisis of traditional paradigms of research. He emphasized the idea that modern philosophy needs a new identity, certain methodological adjustments, including a synthesis of rational, spiritual 
and holistic vision of the world, an integration of cognitive and axiological resources (Mezhuev, 2011).

The current turbulent political, economic, social and educational issues urgently call for a philosophical interpretation, but can it be provided by modern philosophy? Annual events, e.g., Association of the Scientific Study of Consciousness conference in Buenos Aires, have raised this issue (Goldhill, 2016). Philosophers have actively commented on how the role of philosophy has been limited to providing work for squads of university professors, many of whom certainly understand that what they teach is not philosophy but a prescribed set of concepts, judgements and estimates. Below are some of the most recent opinions expressed by philosophers of considerable renown on their blogs and other social media.

"Philosophers today exist in the Academy, as members of departments of philosophy in universities, as professional teachers of a more or less theoretical subject known as philosophy" (Barrett, 1958). "Philosophers often risk their professional reputations when they appear on television or write for newspapers or magazines... Philosophers talk only to their own kind and not even to all philosophers" (Sinnott-Armstrong, 2015). "Philosophy is relevant in ways that do not serve the interests of those in power" (Wilkins, 2011). "A great deal of philosophy doesn't really deserve much of a place of the world. Philosophy in some quarters has become self-indulgent, clever play in a vacuum that's not dealing with problems of any intrinsic interest" (Dennett, 2016).

On the other hand, Massimo Pigliucci, a biologist and philosopher at the City University of New York, is more optimistic in his assessment of the role and status of philosophy in the modern world. Contrary to a wide-spread belief that "philosophy is a useless enterprise" he claims that "there is more active, vigorous, interesting, and intellectually respectable philosophy to be explored" (Pigliucci, 2014).

In an attempt to answer the aforementioned question about the nature of true philosophy, as well as to reveal the causes, mechanisms and outcomes of philosophy losing its relevance in the modern world, it is helpful to 1) follow the changes of philosophical thought throughout history; 2) discover the status and meaning of modern philosophy; 3) outline a perspective direction of development of modern philosophy.

\section{MATERIALS AND METHODS}

The methods employed to pursue these objectives are as follows: analytical, historical, cultural, comparative and hermeneutical. The analytical method enables the researcher to achieve definite answers in response to certain questions; the historical method allows 
accounting for the development of the issue from the past to the present in a coherent and evidence-based way; the cultural method is used to gain insights into the way philosophy interacts with culture, and to reveal the implications of such interaction; the comparative method aims to make comparisons between the ways philosophical thought in Russia and in the West has influenced, and been influenced by, modern politics, social trends and other factors; the hermeneutical method is used to interpret works of modern and contemporary philosophers and other texts relevant to the issues studied.

\section{RESULTS}

The research has led to a number of conclusions:

1) The inability of modern philosophy to address urgent political, social, etc. issues in Russia is the result of its deliberate three-stage transformation into ideology throughout the $20^{\text {th }}$ century.

2) Modern philosophy, both in Russia and abroad, cannot be narrowed down to history and philosophy of science, because issues of human existence (i.e. Being) lie beyond the scope of science. Modern philosophy is the philosophy of culture.

3) The ultimate goal of unraveling the meaning of modern philosophy is to go from the philosophy "about something" to the philosophy of the person generated by his/her independent thought. This kind of further development is only possible in the situation of academic freedom and the person's independence in finding and absorbing knowledge.

\section{DISCUSSION}

A historical overview of the three-stage "suppression of philosophy" in Russia and its impact on education

In April 1987 the Philosophical Community Meeting was held to consider such issues as the relationship between philosophy and real life, situation in which Soviet philosophy was at the moment, its status, problems and measures to solve them. In response to a question of an anonymous questionnaire, "How to ensure connection between philosophy and the real life?" one of the Meeting participants wrote, "First of all, both philosophy and life should exist" (Voprosy, 1987). Among the answers there were a lot of other fine judgements and critical comments; some of them, certainly, brought up vital problems. However, hardly anybody understood at that time that it would entail strategic changes in attitude to philosophy and that the philosophy itself in the form known to most of the Meeting participants would soon disappear. It is likely that the Meeting was summoned for the sole purpose of convincing the 
general public (as well as the Meeting participants) of irrelevance of the contemporary philosophy.

When the Marxist-Leninist philosophy ceased to be an obligatory university course in Russian universities, it was promptly replaced with numerous manuals and textbooks that retold the basics of the same philosophy in a "new way" or focused on details of lives of certain philosophers and authors' views on some important, in their opinion, issues. Lately even that post-Soviet - philosophy has been actively eliminated: it has been excluded from the list of compulsory courses; the number of academic hours allocated for philosophy courses is reduced; and the respective qualifying examination for the Candidate degree has been abolished. It is a recurrence of what has happened repeatedly throughout the history of national education. Vanchugov (1994) wrote, "Harmfulness of philosophy is a stable ideological myth among Russian officials, and their fear of philosophy could compete only with the fear of typhoid fever that had regularly visited Russia".

The official attitude to philosophy was expressed in a well-known saying of the middle of the XIX century, "The benefit of philosophy is not proven, but the harm associated with it is quite possible." It is known that at that time teaching of philosophy at universities was reduced to courses in logic and psychology. They were read by professors of theology, not secular philosophers, under the programs prepared and approved by the department of religious affairs. In fact, the ideas totally excluded from them belonged to the classics of German philosophy and positivists, and they had already become relatively well-known by that time in Russia.

It happened again 70-80 years later. However, as it often happens in our homeland, the scenario was exactly the opposite. The Russian religious philosophy that had greatly developed by that time was banished, giving way to hastily trained secular philosophers who could teach the science about "the universal laws of development of nature, society, and thought". It was not difficult to teach the science, but one could only call it philosophy in the most general sense, i.e. in the context of a general schematic approach. The philosophers themselves clearly understood it. They expressed their doubts about the official concept of philosophy through an exaggerated interest in the issues of the cognitive theory and history and philosophy of science.

In the 1970-80s the most popular ideas were associated with the names of Quine, Kuhn, Lakatos, Popper, Feyerabend and others. The essence and the idea of philosophy narrowed down to one of three - actually philosophical, according to Kant, - questions: What can I know? However, neither Russian nor above-listed foreign authors were pioneers in such 
narrowing of the research scope and substitution of philosophy with science, including cognitive theory. The positivists had done the same long before them. They are known to have considered philosophy to be just an "ignoramus" in comparison with the positive science. Here is how Bogdanov (1986) expounded the idea about a century ago, "Of course, any (italics mine - V.P.) philosophy is an expression of weakness and fragmentation of knowledge, a deficiency of scientific development; it is an attempt to provide a unified picture of being, filling in the gaps in scientific experience with speculations; therefore philosophy will be eliminated... by the monism of science".

However, Karl R. Popper, who considered himself to be in opposition to positivism, also wrote in his small essay "How I See Philosophy", "I consider the issues of the cognitive theory to be the core of both common-sense, non-critical philosophical ideas and academic philosophy" (Popper, 1991). In the last quarter of the XX century, this attitude, which for some reason is not considered to be positivist, was shared not only by influential Russian philosophers but also by natural scientists. They considered it to be more realistic and scientific than the annoying official concept of philosophy. It was absurd and unethical to deny philosophy in general, but it had to be a science. However, they essentially had nothing to say about philosophy as a science, except what had already been said by Hegel or stated in the Marxist-Leninist doctrine and positivist concepts, so it had to be the philosophy of science. By the beginning of the XXI century, this attitude had also been firmly established in the educational policy of Russia.

Secret doubts about the official concept of philosophy were apparent among Russian philosophers as early as the 1970s. An "epistemological turn" started at the same time. Those doubts and that turn finally, thirty years later, resulted in another "suppression of philosophy" in Russia (Yakhot, 1991). It is the third suppression of philosophy in our history. Of course, it is not as blatant as in the middle of the XIX century and in the 1920-30s: the Russian officials have definitely learned something. The Soviet philosophers also learned a lot. At that time they could not, of course, openly oppose the official concept of philosophy as a science. However, they shifted their priorities and narrowed the object of their research, replacing it with the philosophy of science. In other words, the latest suppression of philosophy in Russia was mainly prepared by philosophers themselves.

The three suppressions make a consistent pattern. Actually, as a result of each of them philosophy was again transformed into ideology, i.e. a system of beliefs that ultimately serves the interests of the ruling elite and has a definite apologetic aim - to justify the existing social arrangements and foster the required unanimity of opinions in the society. Time differences 
do not matter in this regard. Philosophy, as any other system of beliefs sanctioned by the authorities and approved in education, in any epoch becomes an ideology. Nowadays, the process has become so obvious that some theorists have been able to speak about the appearance of a new social structure: the international ideocracy (Lukin, 2016). Russian religious philosophy had played the role of ideology since the middle of the XIX century and was replaced by the Marxist-Leninist philosophy in the 1920-30s. The beginning of the XXI century in Russia was marked by formation of a new ideology - the history and philosophy (methodology) of science.

The new ideology is actually a converted form of science - its phantom, apparition apparently speculating on the respect for science, which is still preserved in the society. On the other hand, this ideology is another attempt to turn philosophy into a science, presented as an effort to bring up philosophy from its "ignoramus" state. Keeping the term "philosophy", supposedly out of respect for it, does not change anything in fact. It is actually suppression of philosophy. As a matter of fact, the content of the philosophy of science is confined to its object, so there is neither science nor philosophy in the proper sense in this new ideology, which does not reduce its value. First, the ideology does not need any scientific or philosophic properties, as it easily takes the form of both science and philosophy. Fragments of both of them are skilfully used in the ideology to achieve the above-mentioned goal - to foster singlemindedness among many individuals. Second, the philosophy of science is a new ideology with all properties of the information society epoch. Third, it can therefore be easily integrated in the education of almost any profile, disguised as contemporary philosophy. This automatically eliminates any difficulties experienced by philosophy teachers while presenting totally outdated information.

Thus, the contemporary liberal arts education serves to foster the following view among students: the true philosophy is philosophy of science, while philosophy per se does not deserve serious attention because such philosophy is a relic of the past.

\section{The estrangement of philosophy from itself in Western philosophical discourse}

In the West, the theme of the "death of philosophy" has been seriously discussed since the middle of the last century. Oizerman (1979) wrote about it, "Modern bourgeois philosophy does not evolve from myth to reason, but rather from reason to mythology. And the bourgeois concept of the death of philosophy, despite the fact that it reflects quite definite facts, is a myth that is clearly refuted by the creative development of dialectical materialism". 
The fate of the "creative development" is well known: dialectical materialism already looked frozen in the decisions of the latest Congresses of the CPSU. Still this only partly confirms the correctness of the "bourgeois concept of the death of philosophy". Doubts that dialectical materialism is true philosophy could be heard even in the days of its triumph. Now that its triumph is in the past, it has become apparent that it is really not a true philosophy. At the same time, it is undeniable that there were philosophical, quite reasonable and critical ideas in dialectical materialism, and they were developed by Soviet philosophers without regard to the triumph of ideology. It was a triumph of the concept (the system) that had been set forth by the ideological leaders and was later approved as a true philosophy. Over time it took the form of mythology, i.e. knowledge based on tradition and faith. In due course dialectical materialism suffered the same fate as any other mythology.

Lukach (2005) pointed out that the "revaluation of values" has been going on for too long and interpreted it as a sure sign of philosophy "getting lost". Krasikov (2013) defined the ways philosophy reacted to the explosion of ideological, technological, economic, social and political transformations: it turned to methodologies of specific fields of study, or explored highly abstract matters, or chose mass-oriented Socratic philosophizing and moral reflection, completely losing its original universal and comprehensive nature.

However, it does not mean that the very idea of philosophy should suffer the same fate. It is all about finding an adequate form of its presentation and teaching - the form that would not make philosophy a servant of theology, politics or science. Search for such form has been carried out throughout the history of philosophy. Hegel, for example, wrote in one of his letters on teaching philosophy at universities, "The particular sort of embarrassment presently observed in the teaching of philosophy surely has its source in the new direction this science has taken, giving rise to the current situation in which its former scientific development and the special sciences into which its subject matter was divided have become more or less antiquated in form and content. Yet the idea of philosophy (italics mine - V.P.) which has taken their place still finds itself without scientific development, and the subject matter of the special sciences has been transformed and integrated with this new idea only incompletely or not at all" (a. Hegel, 1970). Hegel was worried both about the form of teaching philosophy and a real possibility of dissolution of its ideas in sciences, "...I simply wish to indicate the following singular phenomenon: a philosopher, like anyone else, treats within one and the same science [philosophy] a few more or less or otherwise diverse sciences" (d. Hegel, 1970). Hegel did not agree with a trend, prevalent in his time, to present philosophy as the sum of superficial knowledge acquired about different sciences. However, by bringing his teachings 
to a system he also gave cause for failing to see that there was something extra-scientific in philosophy, something beyond understanding by any science, but as significant as the scientific knowledge, and, maybe, even more important for the mankind than all sciences taken together. At the same time, Hegel understood that, apart from the systematized philosophical knowledge, there is another - real - philosophy.

In 1805-1806, when Hegel was preparing materials for his lectures in Jena, he named the course "Jena Realphilosophie". The work set out (in the form of a system, of course) his entire philosophy (Hegel, 1969), parts of which were later presented in other papers. Hegel considered philosophic knowledge to be restored spontaneity - a sensuous consciousness divided between nature and self-recognition. Hegel wrote about philosophy that became estranged from itself, coming back "to its beginning, to the immediate consciousness that is divided" (c. Hegel, 1970). Moreover, in one of the notes to his text he emphasized, "Activity is extinguished in the product" (b. Hegel, 1970). The product of Hegel himself - his system suffered that fate, because the philosophical knowledge, when brought to a system and existing as only a text alienated from the philosophizing mind, continues functioning under the laws of another - non-philosophical - genre.

\section{Philosophy of culture as the modern way of philosophizing}

Does the idea that philosophy as a system is alienated from the philosophising mind mean that the philosophy presented as a system is not philosophy anymore? We believe it does. Contrary to popular perception, we can definitely state that a system does not reflect well on philosophy. Any system in philosophy is a myth - a convenient simulacrum, not so much reflecting the truth as concealing it. Systemization is essential for the purposes of philosophical propaedeutic. However, any system excludes the idea of human existence, and philosophy is born with the doubt about such existence. This doubt is resolved through demythologization of the mind, which is actually the meaning of philosophizing. Philosophy is opposition of the idea to the system of its presentation.

Science is definitely worth philosophizing, but it does not mean that philosophy of science is the true philosophy. Staying within scientific frames, we would not be able to understand a lot of things: the meaning and purpose of human relationships and a human being's life, specifics of the human inner world, a human being's role in culture and role of culture itself and scientific knowledge in general.

Of course, today's science has long ceased to be classical science of former times. Today, according to Prigogine (1989), "the world we see outside us and the world we see within are 
converging. This convergence of two worlds is perhaps one of the important cultural events of our age". In other words, science is close to dealing with matters that have long been considered to be purely philosophical, i.e. it doubts its own self-sufficiency. There is a certain pattern in this transformation: once a spin-off from philosophy, the science will inevitably "spin in". It will have to answer the question why its picture of the world is ultimately consistent with the human being, deal with the Being dependence on the human existence and explain why the human being is so alone in the universe.

These are issues that cannot be considered only within philosophy of science, as they are obviously related to culture. Therefore, philosophy of culture should be the modern way of philosophizing and the true philosophy of our time. There are a lot of problems with this concept. In spite of the fact that the notion of philosophy of culture has already existed for over two centuries, it is still a collection of sayings and schematic representations of culture. Definition of the essence of culture is still an open issue, as well as the mechanism of its selfgeneration, i.e. the ability to create itself, which is an undeniable prerogative of the spirit. Another important issue is related to the laws of culture development, which, apparently, cannot be fundamentally different than those formulated by Hegel in his dialectic (Larin, 2011). In the context of such laws we have to consider another issue: correlation between culture and life. These two spheres of being are not equal, and they painfully -for life correlate to each other (Gurevich, 2013).

We also can't but raise an issue of inherent prevalence of the demiurgic principle in culture, which represses its sacral principle. The word "culture" itself is associated above all with the idea of something created, cultivated and processed rather than with the concepts of respect, esteem and love. That could be reason for the natural transformation of culture into civilization. Finally, the question about the meaning and purpose of human cultural development is not resolved - people instead are focused on the significance and results of their development. It seems both the meaning and purpose are determined by the culture itself. No wonder that the human being's picture of the world is essentially a picture of culture. It cannot be otherwise because people today, as a rule, cannot imagine themselves outside culture (Polishchuk, 2006).

We can assume that philosophy of culture will be the last philosophy "of something". The idea of the philosophy is education and culture as a kind of being, created by its carrier and therefore defining the entire originality of the species Homo sapiens. Its logical replacement could be philosophy of a human being with the respective idea. We want to emphasize: it would not be philosophy about a person but philosophy of the person generated by his/her 
independent thought. We need some "minor things" to achieve it: university autonomy, or "academic freedom" (Mamardashvili, 1996), and real education instead of standard training. The training results in qualification, i.e. usefulness of a person for culture. The education, on the contrary, ensures culture usefulness for the person, as it gives him/her the ability to be independent in finding and absorbing new knowledge, without identifying their beliefs with that knowledge. It is necessary that people studied for their own sake, not for the sake of culture. It is a pre-condition for the new philosophy of a human being. If only human beings would not be "extinguished" earlier in their product, i.e. in culture.

\section{CONCLUSION}

The role and status of modern philosophy have been a topic of numerous discussions both in recent scientific papers and on social media. Philosophers and scientists obviously feel the need for a philosophical interpretation of the ongoing crisis, the abrupt changes to habitual ways of life and patterns of thought and behavior experienced by people in different parts of the world. This article argues, however, that the modern philosophical thought is hardly adequate to meet this need.

An important cause of such a decline of philosophy is seen in the fact that throughout the $20^{\text {th }}$ century philosophical thought, both in the West and in Russia, has undergone a number of major reconsiderations, with controversial outcomes.

This article demonstrates that the deliberate process of transforming philosophy into ideology had three distinct stages in Russia. The first stage started in the middle of the XIX century when teaching of philosophy at universities was reduced to courses in logic and psychology. The second stage took place when the Marxist-Leninist philosophy was forcefully inculcated in the 1920-30s. The third stage was marked by another shift in priorities and a narrowing of scope at the beginning of the XXI century. It saw a replacing of philosophy per se with the philosophy of science.

As a result of the three "suppressions of philosophy" a system of beliefs has emerged, that ultimately serves the interests of the ruling elite and has a definite apologetic aim - to justify the existing social arrangements and foster the required unanimity of opinions in the society. Liberal arts students and anyone pursuing philosophical studies are taught that the true philosophy is philosophy of science, while philosophy per se does not deserve serious attention because such philosophy is a relic of the past.

On the strength of the fact that there are many cultural issues that need philosophical consideration, but are beyond the scope of science, the authors conclude that the philosophy 
of culture is the modern way of philosophizing and the true philosophy of our time. The article highlights some unresolved issues connected with this approach: the essence of culture; the principles, laws and the purpose of cultural development; the correlation between culture and life.

The article also argues that the ultimate goal of unraveling the meaning of modern philosophy is to go from the philosophy "about something" to the philosophy of the person generated by his/her independent thought. This kind of further development is only possible in the situation of academic freedom and the person's independence in finding and absorbing knowledge.

The contribution of this study to the contemporary philosophical discourse is threefold: firstly, it demonstrates that the role and status of modern philosophy are different from and surpass those of narrower fields of knowledge; secondly, it defines modern philosophy as the philosophy of culture; thirdly, it envisions the future of modern philosophy as the philosophy generated by the person capable of independent thinking.

This study can be applied to interpreting and evaluating current and past social issues from a cultural and philosophical standpoint.

\section{REFERENCES}

1. Barrett, W. (1958). Irrational Man. Quote comes from Sykes, G., 1964. Alienation: The Cultural Climate Of Our Time. New York, 2: 967-970. In Philosophers' Role In

Societyhttp://philosophicalsociety.com/Archives/Philosophers'\%20Role\%20In\%20Society.ht m

2. Bogdanov, A.A. (1986). Krasnaya Zvezda [Red Star]. In Russkaya literaturnaya utopiya [Russian Literary Utopia]. Moscow: MSU Publishing, p: 287.

3. Dennett, D. (2016). A Tribute to Daniel Dennett's Consciousness. 20th annual meeting of the Association for the Scientific Study of Consciousness.

4. Goldhill, O. (2016). One of the most famous living philosophers says much of philosophy today is "self-indulgent”.https://qz.com/768450

5. Gurevich, P.S. (2013). Zhiznenny mir cheloveka [World of Human Life]. Filosofija i kul'tura [Philosophy and Culture], 1(61): 7-8.

6. Hegel, G.W.F. (1969). Jenaer Realphilosophie. Lecture manuscripts for the philosophy of the nature and the spirit 1805-1806 (Vorlesungsmanuskripte zur Philosophie der Natur und des Geistes von 1805-1806). Akademie, Berlin. 
7. a. Hegel, G.W.F. (1970). Raboty raznyh let [Works of Different Years]. 2 vols. Vol. 1. Moscow, pp: 419-420. [Translator's note: Engl. quote comes from Hegel to von Raumer: Nuremberg, August 2, 1816. In Hegel (1984). The Letters. Ed. By C. Butler and Ch., Purdue Research Foundation].

b. ibid., p: 298.

c. ibid., p: 385 .

d. ibid., p: 424.

8. Krasikov, V.I. (2013). "Death of Philosophy" and Fight for its Legacy: Interdisciplinary Demarcation and Literary Philosophical Hybrids. Bulletin of Kemerovo State University of Culture and Arts, 23. http://cyberleninka.ru/article/n/smert-filosofii-i-borba-zaee-nasledstvo-mezhdistsiplinarnye-razmezhevaniya-i-literaturno-filosofskie-gibridy.

9. Larin, Yu.V. (2011). Sposob bytija kul'tury [Mode of Culture Being]. In Problemy teorii i istorii kul'tury: mezhvuzovskij sb. nauch. tr. [Issues of Theory and History of Culture: Inter-University Collection of Scientific Papers], Ishim, 1: 30-38.

10. Lektorsky, V.A. (2012). Filosofiya, poznaniye, kultura [Philosophy, cognition, culture]. Moscow: Canon+, p: 8.

11. Lukach, G. (2005). The Crisis of Bourgeois Philosophy. Philosophy and Society, 3(40): 160-188.

12. Lukin, A. (2016). The Emerging International Ideocracy and Russia's Quest for Normal Politics. Strategic Analysis, 40(4), pp: 255-270.

13. Mamardashvili, M.K. (1996). Neobkhodimist' Sebya. Vvedeniye v Filosofiyu. [The Necessity of Oneself. An Introduction to Philosophy]. Moscow: Labyrinth.

14. Mezhuev, V.M. (2011). Istoriya, tsivilizatsiya, kultura: opyt filosofskogo istolkovaniya [History, civilization, culture: a philosophical interpretation]. St. Petersburg: SPSUTU.

15. Nikiforov, A.L. (2013). Review of Philosophy, cognition, culture by V.A. Lektorsky. Voprosy filosofii, 4: 170-175.

16. Oizerman, T.I. (1979). Burzhuazniy mif o smerti filosofii [Bourgeois Myth on Death of Philosophy]. Voprosy filosofii, 9: 136.

17. Pigliucci, M. (2014). Neil deGrasse Tyson and the value of philosophy. https://scientiasalon.wordpress.com/2014/05/12/neil-degrasse-tyson-and-the-value-ofphilosophy.

18. Polishchuk, V.I. (2006). Terminy "kul'tura", "zhizn'" i im soputstvujushhie [Terms 'Culture', 'Life' and Others Associated with them]. In Etika, moral', nravstvennost': Rossija i 
sovremennyj mir [Ethics, Morals, Morality: Russia and the Contemporary World]. Proceedings of Symposium, Tyumen, pp: 182-185.

19. Popper, K.R. (1991). Kak ya ponimayu filosofiyu [How I See Philosophy]. In Perspektivnye problemy filosofskih issledovanij za rubezhom [Prospective Issues of Philosophical Studies Abroad]. Moscow, p: 121.

20. Prigogine, I. (1991). The Philosophy of Instability. (In Russian). Voprosy filosofii, 6: 48. [Translator's note: Engl. quote comes from Prigogine, I. (1989). The Philosophy of Instability. Futures, 21(4): 396-400].

21. Proceedings of the Philosophical Community Meeting 14 - 16 April 1987. Voprosy filosofii (1987), 9: 78.

22. Sinnott-Armstrong, W. (2015). Does philosophy matter? The OUPblog Tenth Anniversary Book, pp: 149-151. http://blog.oup.com/2015/03/does-philosophy-matter/ 23. Vanchugov, V.V. (1994). Ocherk istorii filosofii "samobytno-russkoy" [Sketch of the History of "Originally Russian" Philosophy]. Moscow: Piligrim, p: 85.

24. Wilkins, J.S. (2011). The nature of philosophy and its role in modern society. http://evolvingthoughts.net/2011/02/the-nature-of-philosophy-and-its-role-in-modern-society/ Feb 62011

25. Yakhot, I. (1991). Podavlenie filosofii v SSSR (20-30 gody) [Suppression of Philosophy in the USSR: 1920-30s]. Voprosy filosofii, 9: 44-68.

\section{How to cite this article:}

Viktor I Polishchuk, Zoya Ya. Selitskaya, Grogory V. Silchenko, Evgenia A. Yurinova, Irina G. Vyushkova. On the idea of true philosophy. J. Fundam. Appl. Sci., 2017, 9(1S), 742-755. 